\title{
Characterization of a cDNA encoding cystatin with antifungal activity from Siam tulip Curcuma alismatifolia
}

\author{
Ruangwit Porruan $^{\mathrm{a}}$, Ruttaporn Chundet ${ }^{\mathrm{b}}$, Somboon Anuntalabhochai ${ }^{\mathrm{a}, \mathrm{c}, *}$ \\ a Department of Biology, Faculty of Science, Chiang Mai University, Chiang Mai 50200 Thailand \\ b Division of Biotechnology, Faculty of Science, Maejo University, Chiang Mai 50290 Thailand \\ c Biotechnology Unit, University of Phayao, Phayao 56000 Thailand
}

*Corresponding author, e-mail: soanu.1@gmail.com

Received 20 Jan 2013

Accepted 11 Jul 2013

\begin{abstract}
Cystatins are cysteine protease inhibitors involved in defence mechanisms against pests and pathogens. Here, the cystatin CaCPI gene was isolated from a cDNA library of the Siam tulip (Curcuma alismatifolia cv. Chiang Mai Pink). The full length cDNA of 601 bp contains 372 bp of an open reading frame encoding 123 amino acids flanked by $5^{\prime}$ and $3^{\prime}$ untranslated regions of 32 and $197 \mathrm{bp}$, respectively. The deduced amino acid sequence consists of a putative N-terminal secretory signal peptide of 22 amino acids and an estimated molecular mass of $11.2 \mathrm{kDa}$ of the mature protein. The $\mathrm{CaCPI}$ protein contains all of the highly conserved blocks included $\mathrm{Gly}^{31}-\mathrm{Gly}^{32}$, the reactive site motif QXVXG $\left(\mathrm{Q}^{76} \mathrm{~V}^{77} \mathrm{~V}^{78}\right.$ $\left.\mathrm{A}^{79} \mathrm{G}^{80}\right)$, the $\mathrm{P}^{106}-\mathrm{W}^{107}$, and the [LVI]-[AGT]-[RKE]-[FY]-[AS]-[VI]-X-[EDQV]-[HYFQ]-N $\left(\mathrm{L}^{49} \mathrm{G}^{50} \mathrm{R}^{51} \mathrm{~F}^{52} \mathrm{~A}^{53} \mathrm{~V}^{54} \mathrm{D}^{55} \mathrm{Q}^{56}\right.$ $\mathrm{H}^{57} \mathrm{~N}^{58}$ ) block that is common among plant cystatins. The CaCPI gene was cloned into a pDEST17 expression vector and was then transformed into Escherichia coli strain BL21-Star to produce a recombinant CaCPI protein. After induction with $1 \mathrm{mM}$ IPTG, the cell lysate of $E$. coli-carrying pDEST17-CaCPI generated a CaCPI protein about $12 \mathrm{kDa}$ in size as measured using SDS-PAGE. Pre-incubation of the 5-30 $\mu \mathrm{M}$ CaCPI protein samples with $5 \mu \mathrm{M}$ papain is known to decrease papain activity. Antifungal activities of the purified recombinant CaCPI protein against phytopathogenic fungi were tested. The CaCPI protein could suppress mycelium growth of Fusarium oxysporum, Colletotrichum capsici, and Pyricularia grisea phytopathogenic fungi.
\end{abstract}

KEYWORDS: cysteine protease, cysteine protease inhibitor, phytopathogenic fungus

\section{INTRODUCTION}

The cysteine protease inhibitors or cystatin superfamily regulates the proteolytic process of papain-like cysteine protease by binding to the active site of the target enzyme. In this superfamily, there are three commonly conserved motifs that are important for the protease inhibition activity. The first motif is the reactive site motif QXVXG, which physically interacts with the active site. The second motif contains the PW residues located in the C-terminal region of the protein. The last active site is a glycine residue near the $\mathrm{N}$-terminal region of the inhibitor ${ }^{1-3}$.

Cystatins exist widely in many organisms from microbes to plants and animals. In plants, several roles have been attributed to these proteins including the control of endogenous cysteine protease in physiological and developmental processes such as the development of stem and leaves ${ }^{4}$, protein turnover during seed maturation, and germination ${ }^{5-7}$ and programmed cell death ${ }^{8}$. Several lines of evidence suggest that plant cystatins are also responsive to abiotic stresses such as drought, salt, ABA and cold treatment and this helps plants to improve their ability to tolerate environmental stress ${ }^{9-13}$. In addition, plant cystatins have a significant role in the plant defence mechanisms where they inhibit the activities of digestive cysteine proteases of herbivorous arthropods, field slugs, and parasitic nematodes ${ }^{14-17}$. Furthermore, some plant cystatins have been shown to have detrimental effects against pathogenic fungi ${ }^{13,18-22}$.

Plant disease is the one of major limiting factors for world-wide food production. Since plants do not have an immune system to protect them from pathogens, plant infections can result in significant crop loss globally ${ }^{23}$. More than $70 \%$ of all major crop diseases are caused by fungi ${ }^{24}$. The fungi Fusarium oxysporum, Colletotrichum capsici and Pyricularia grisea are the important and common fungal species which can cause significant economic damage to crops worldwide particularly in tropical, subtropical, and temperate regions. The fungus $F$. oxysporum can cause vascular wilt on more than 100 cultivated plants such as cereals, tomatoes, potatoes, bananas, and 
water melons ${ }^{25,26}$. C. capsici is known to cause the anthracnose disease for many economically important plants such as pepper (Capsicum spp. ${ }^{27-29}$, and papaya (Carica papaya $)^{30,31}$. The fungus $P$. grisea (teleomorph = Magnaporthe grisea) is known to be the causal agent of the rice blast disease. This disease is considered to be the most prevalent fungal disease of rice because of its wide distribution and destructiveness and high degree of pathogenicity ${ }^{32,33}$. Hence cystatin from Siam tulip was tested for antifungal activities against these three pathogenic fungi.

In this study, the Curcuma alismatifolia CPI homologue gene $(\mathrm{CaCPI})$ was cloned from the Siam tulip cDNA library. The sequence analysis was performed and protein expression in bacterial system and protein purification were carried out. The protein activities and antifungal assays in growth inhibition of some plant fungi were also examined.

\section{MATERIALS AND METHODS}

\section{Cloning of the CaCPI gene from the Siam tulip cDNA library}

Bract samples of the Siam tulip were prepared for mRNA isolation using the standard TRIzol reagent (Invitrogen, USA). The Creator SMART cDNA Library Construction Kit (Clontech, USA) was then used to generate the cDNA library according to the manufacturer's instructions. DNA sequence analysis of the double-strand recombinant plasmids was performed using the dideoxynucleotide chain termination method ${ }^{34}$ incorporating an autosequencer (ABI). The CaCPI cDNA was identified directly from the sequenced EST clones using BLASTX against the data in the current non-redundant protein database of GenBank (www.ncbi.nlm.nih.gov). The signal peptide was analysed using the SignalP 4.0 server (www.cbs.dtu.dk/services/SignalP).

\section{Sequence alignment and phylogenetic analysis}

The CaCPI protein sequence was aligned to other known plant cystatins retrieved from GenBank using ClustalW2 from the EMBL-EBI database (www.ebi. ac.uk/Tools/msa/clustalw2/). The other plant cystatins which had been characterized previously were chosen to compare the Siam tulip cystatin sequence as a measure of similarity and to ensure the required active sites were presented in the newly discovered Siam tulip cystatin.

\section{Expression of a recombinant Siam tulip cystatin in E. coli}

A $C a C P I$ fragment without a secretory signal sequence was amplified from the pDNR-CaCPI vector and cloned into the entry vector pENTR-3C (Invitrogen, USA). Then the CaCPI gene was transferred to the Gateway E. coli expression vector pDEST17 with the $6 \times$ His tag using the clonase reaction resulting pDEST17-CaCPI. The pDEST17-CaCPI product was then transformed into E. coli BL21 (DE3) cells using the electroporation technique. Cells containing the pDEST17-CaCPI construct were grown at $37^{\circ} \mathrm{C}$ in LB liquid medium until $\mathrm{OD}_{600}$ of $0.5-1$ was reached. The recombinant CaCPI expression was then induced by the addition of $1 \mathrm{~mm}$ isopropyl- $\beta$-Dthiogalactopyranoside and cultured at $21^{\circ} \mathrm{C}$ overnight.

The recombinant proteins were finally extracted using sonication method and purified by Protino NiIDA 1000 packed His-tag purified columns (5 mg binding capacity per column; Macherey-Nagel, Germany) according to the manufacturing procedure. The purified protein was quantitated with Bradford reagent, ready-to-use (Fermentas, USA) using BSA as a standard protein.

\section{Papain inhibitory activity measurement}

The proteinase inhibition assay using by $\mathrm{CaCPI}$ was determined using BANA $\left(N_{\alpha}\right.$-Benzoyl-DL-arginine $\beta$-naphthylamide hydrochloride) as a substrate according to the previously described method ${ }^{35}$ with some modification. Briefly, different concentrations of $\mathrm{CaCPI}$ were pre-incubated with $5 \mu \mathrm{M}$ papain (Sigma, USA) in an activation buffer $(100 \mathrm{mM}$ $\mathrm{Na}_{3} \mathrm{PO}_{4}, \quad \mathrm{pH}$ 6.5, $10 \mathrm{mM}$ EDTA, $10 \mathrm{mM}$ 2mercaptoethanol) at $37^{\circ} \mathrm{C}$ for $10 \mathrm{~min}$. The reaction was initiated by the addition of $100 \mu \mathrm{l}$ of $200 \mu \mathrm{M}$ BANA as a substrate. The reaction mixture was incubated at room temperature for $20 \mathrm{~min}$ then $300 \mu \mathrm{l}$ of $2 \% \mathrm{HCl}$ in ethanol (w/v) was added at the end to stop the reaction. The chromophore was developed by addition of $300 \mu \mathrm{l}$ of $0.06 \%$ pdimethylaminocinnamaldehyde in ethanol followed by incubation at room temperature for $15 \mathrm{~min}$ and the final measurement of the $A_{540}$. There were 3 replica of each treatment.

\section{Antifungal activity assay of CaCPI}

The phytopathogenic fungi $F$. oxysporum, $C$. capsici and $P$. grise $a$ were cultivated on potato dextrose agar media at $28^{\circ} \mathrm{C}$. Relative fungal growth was estimated by cultivating $10^{4}$ spores of $F$. oxysporum and $C$. capsici or $10^{4}$ conidia of $P$. grisea in a microcentrifuge tube with $1 / 3$ strength of potato dextrose broth (PDB) media and varying the concentration of $\mathrm{CaCPI}(0,5$, 10 , and $20 \mu \mathrm{M}$ ) with $100 \mu \mathrm{l}$ total volume. Ten samples were used in each treatment. The mycelial growth was then monitored by measuring the absorbance 


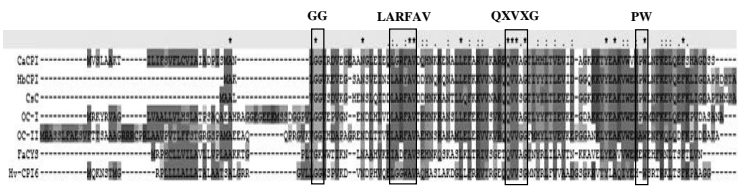

Fig. 1 Sequence alignment of cystatins from the Siam tulip $(\mathrm{CaCPI})$, rubber latex (HbCPI), chestnut $(\mathrm{CSC})$, rice (OCI, OC-II), jelly fig (FaCYS) and barley (Hv-CPI6). The black blocks indicate 4 highly conserved sequences which are common among plant cystatins.

at $492 \mathrm{~nm}$ (BioRad, USA) after $48 \mathrm{~h}$ of culture in $28^{\circ} \mathrm{C}$. Once the growth conditions were satisfied, the actual amount of growth for each fungus was calculated based on ten replicates of the experiment as a percentage of the fungus growth in the absence of CaCPI.

\section{RESULTS AND DISCUSSION}

\section{Sequence analysis of $\mathrm{CaCPI}$}

The cystatin gene was cloned from a cDNA library of Siam tulip. This cDNA fragment (GenBank Accession Number KC176357) comprised 601 nucleotides, including 32 nucleotides of the $5^{\prime}$ untranslated region (UTR) and 197 nucleotides at the $3^{\prime}$ UTR. This sequence also had an internal open reading frame of $372 \mathrm{bp}$ in, encoding a deduced amino acid sequence of 123 residues. Signal peptide analysis using the SignalP software showed that the encoded $\mathrm{CaCPI}$ protein had a putative $\mathrm{N}$-terminal secretory signal of 22 amino acids. The predicted molecular masses of the precursor and the mature protein were 13.5 and $11.2 \mathrm{kDa}$, respectively, (expasy.org/tools/ peptide-mass.html). The CDD search ${ }^{36}$, with the deduced $\mathrm{CaCPI}$ protein sequence showing identity with the conserved cystatin-like domain (CY domain; cd00042).

A BLASTP analysis showed that the deduced amino acid sequence of the $C a C P I$ shared a high level of identity with cystatin sequences from Amaranthus hypochondriacus, Sandersonia aurantiaca, Amblyomma maculatum, Vitis vinifera and Petunia $\times$ hybrid with $86 \%, 78 \%, 78 \%, 77 \%$, and $79 \%$ similarity, respectively. Sequence alignment of the Siam tulip cystatin with other phytocystatins is shown in Fig. 1. The CaCPI sequence contained all of the highly conserved blocks that are essential for cysteine proteinase activity. These conserved regions included the GG doublet $\left(\mathrm{Gly}^{31}-\mathrm{Gly}^{32}\right)$ in the N-terminal region, the reactive site motif $\mathrm{QXVXG}\left(\mathrm{Q}^{76} \mathrm{~V}^{77} \mathrm{~V}^{78}\right.$ $\left.\mathrm{A}^{79} \mathrm{G}^{80}\right)$ and the $\mathrm{A} / \mathrm{PW}$ motif $\left(\mathrm{P}^{106}-\mathrm{W}^{107}\right)$ in the $\mathrm{C}$ -

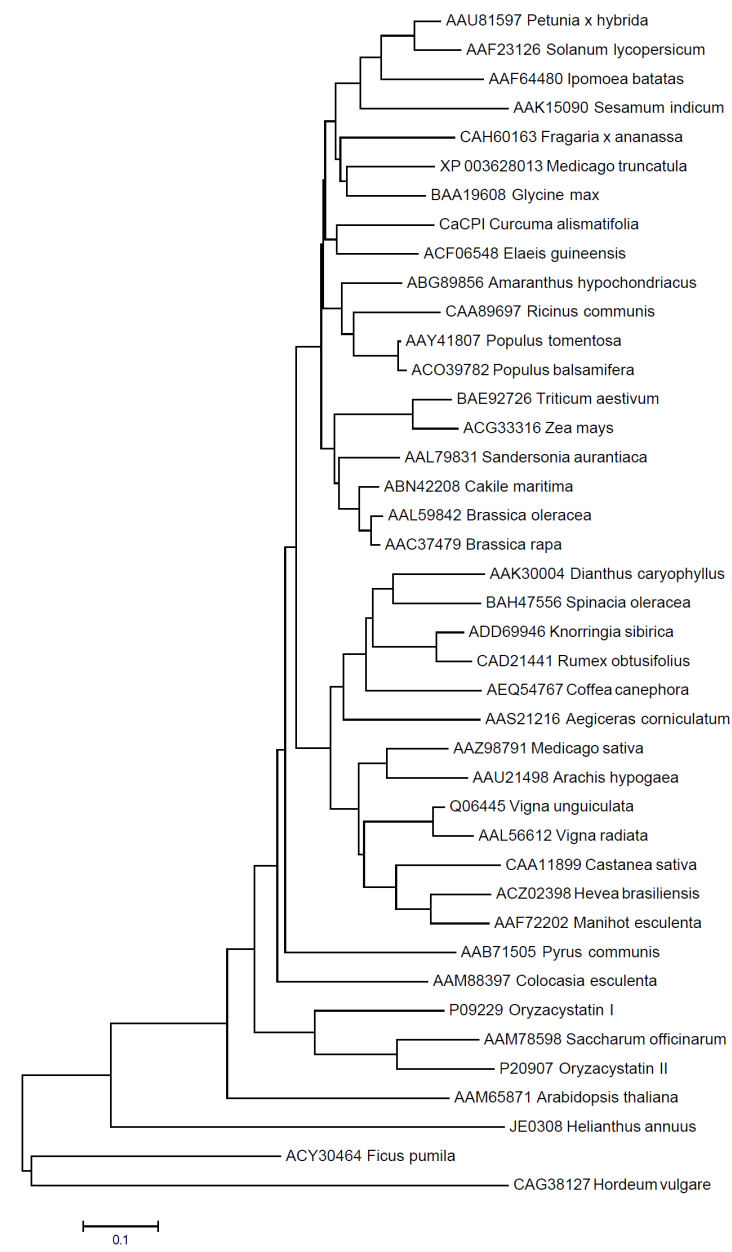

Fig. 2 Phylogenetic tree of the Siam tulip cystatin (CaCPI) and cystatins from 40 different plants.

terminal region. In addition, a unique consensus motif, [LVI]-[AGT]-[RKE]-[FY]-[AS]-[VI]-X-[EDQV][HYFQ]-N ( $\left.\mathrm{L}^{49} \mathrm{G}^{50} \mathrm{R}^{51} \mathrm{~F}^{52} \mathrm{~A}^{53} \mathrm{~V}^{54} \mathrm{D}^{55} \mathrm{Q}^{56} \mathrm{H}^{57} \mathrm{~N}^{58}\right)$, was also found in these phytocystatins ${ }^{37-39}$. The phylogenetic tree (Fig. 2) is based on a 100 sample bootstrapping analysis of the amino acid sequences for CaCPI and other 40 plant cystatins from different species and indicates that the CaCPI sequence for the Siam tulip is most closely related to E. guineensis. The internal node values show the percent conservation from the bootstrapping analysis where values over $50 \%$ are included and values over $80 \%$ indicates that there is a strong consensus for the generated phylogram.

\section{Purification of recombinant proteins from $E$. coli}

The $\mathrm{CaCPI}$ gene was cloned into a pDEST17 expression vector and then transformed into the $E$. coli strain 


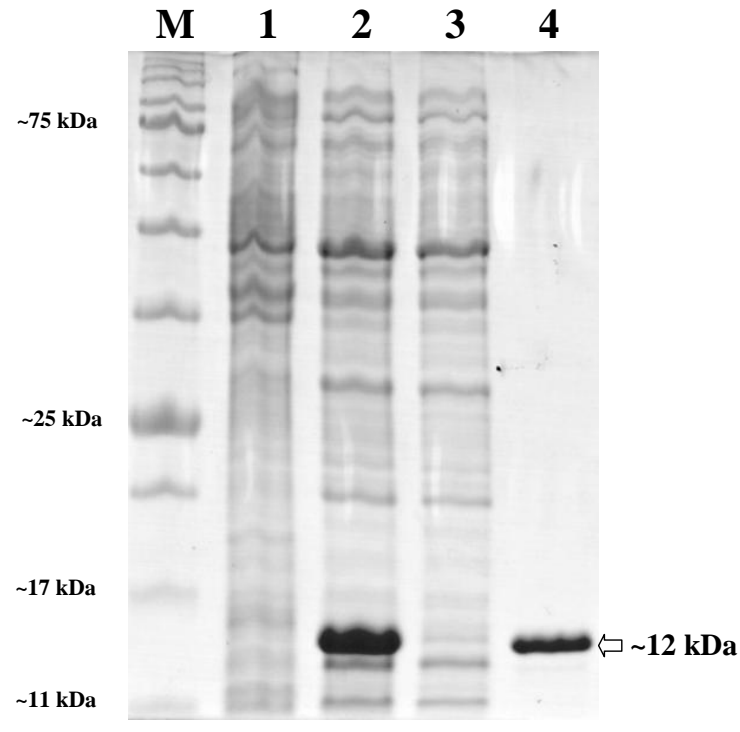

Fig. 3 Bacterial expression of the recombinant CaCPI protein with and without IPTG induction by SDS-PAGE (12\%). Lane (1) total protein fraction before IPTG induction, lane (2) total protein fraction after IPTG induction, lane (3) soluble fraction and lane (4) purified $6 \times$ His-tagged CaCPI protein. Lane (M) molecular weight peptide standards.

BL21-Star for recombinant CaCPI protein production. The recombinant CaCPI expressed in E. coli as a fusion protein with a histidine tag which was in the soluble form and therefore could be purified by affinity chromatography using a Ni-IDA column. The predicted molecular weight of the mature $\mathrm{CaCPI}$ protein without the secretory signal peptide was $11.2 \mathrm{kDa}$. But after automated tagging with $6 \times$ His in pDEST17, its predicted molecular weight increased to $12.06 \mathrm{kDa}$. The single band of the purified His-CaCPI with an apparent molecular mass of approximately $12 \mathrm{kDa}$ in coomassie blue stained SDS-PAGE was observed in an eluted solution from the Ni-IDA column (Fig. 3).

\section{Papain inhibitory activity measurement}

To determine the papain inhibition assay, $5 \mu \mathrm{M}$ of papain was preincubated with various concentrations of purified $\mathrm{CaCPI}$ protein at concentrations ranging from $0 \mu \mathrm{M}$ (control) to $20 \mu \mathrm{M}$. Percentage of residual papain activity $\mathrm{w}$ (Fig. 4). The residual papain activity was decreased when the $\mathrm{CaCPI}$ protein concentration was increased (from $0-30 \mu \mathrm{M}$ ) in the mixture. The previous report demonstrated that, in general, cystatins were a competitive inhibitor of papain ${ }^{21}$. However, the inhibition type of papain activity in some plant species such as rubber latex, corn, rice,

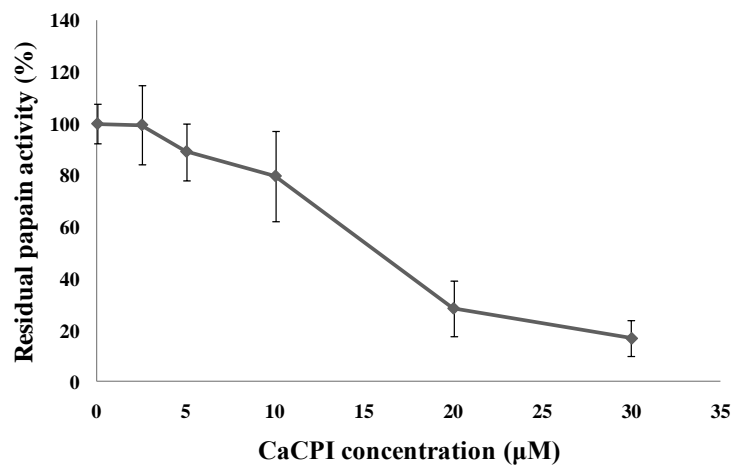

Fig. 4 Inhibition activity of purified CaCPI to papain. The inhibition was expressed as a residual enzyme activity in the presence of different inhibitor concentrations. Papain was incubated at $37^{\circ} \mathrm{C}$ for $10 \mathrm{~min}$ and the residual proteolytic activity was measured using BANA as substrate. Vertical bars represented standard deviations.

soya bean, tomato, and strawberry were shown to be non-competitive inhibition $13,14,19,20$.

\section{Antifungal activity assay}

The effect of purified CaCPI on the growth of fungal plant pathogens was determined using an in vitro bioassay. Purified recombinant CaCPI inhibited the growth of all three phytopathogenic fungi ( $F$. oxysporum, C. capsici, and P. grisea), but the inhibitory effect varied depending on the fungal species. Ten thousand $\left(10^{4}\right)$ fungal spores were cultured in $1 / 3$ PDB with various concentration of $\mathrm{CaCPI}$ protein from 0 (control) to $20 \mu \mathrm{M}$. Then spores or conidia cultures were incubated at $28^{\circ} \mathrm{C}$ for $48 \mathrm{~h}$ without the use of a shaker. Hyphae growths were then measured for their optical density at $492 \mathrm{~nm}$ and used for calculation for relative growth (Fig. 5d).

Hyphae growths of all fungal strains were suppressed after adding CaCPI protein into the medium (Fig. 5). Interestingly, comparison of the sensitivity of CaCPI protein against three pathogenic fungi in this experiment, $P$. grisea was the most sensitive to $\mathrm{CaCPI}$. The growth of $P$. grisea was inhibited up to $90 \%$ in the presence at $5 \mu \mathrm{M} \mathrm{CaCPI}$ in the culture medium but others needed more $\mathrm{CaCPI}$ concentration for inhibit at the same level. Our results agreed with a previous report on barley cystatins ${ }^{40}$. In vitro, most barley cystatins provided a greater growth inhibition in P. grisea than F. oxysporum or Plectosphaerella cucumerina. They explained this result as being due to the different actions of the pathogenic mechanism in different fungal groups. P. grisea was a fungus in the hemibiotrophic group but $F$. oxysporum and 

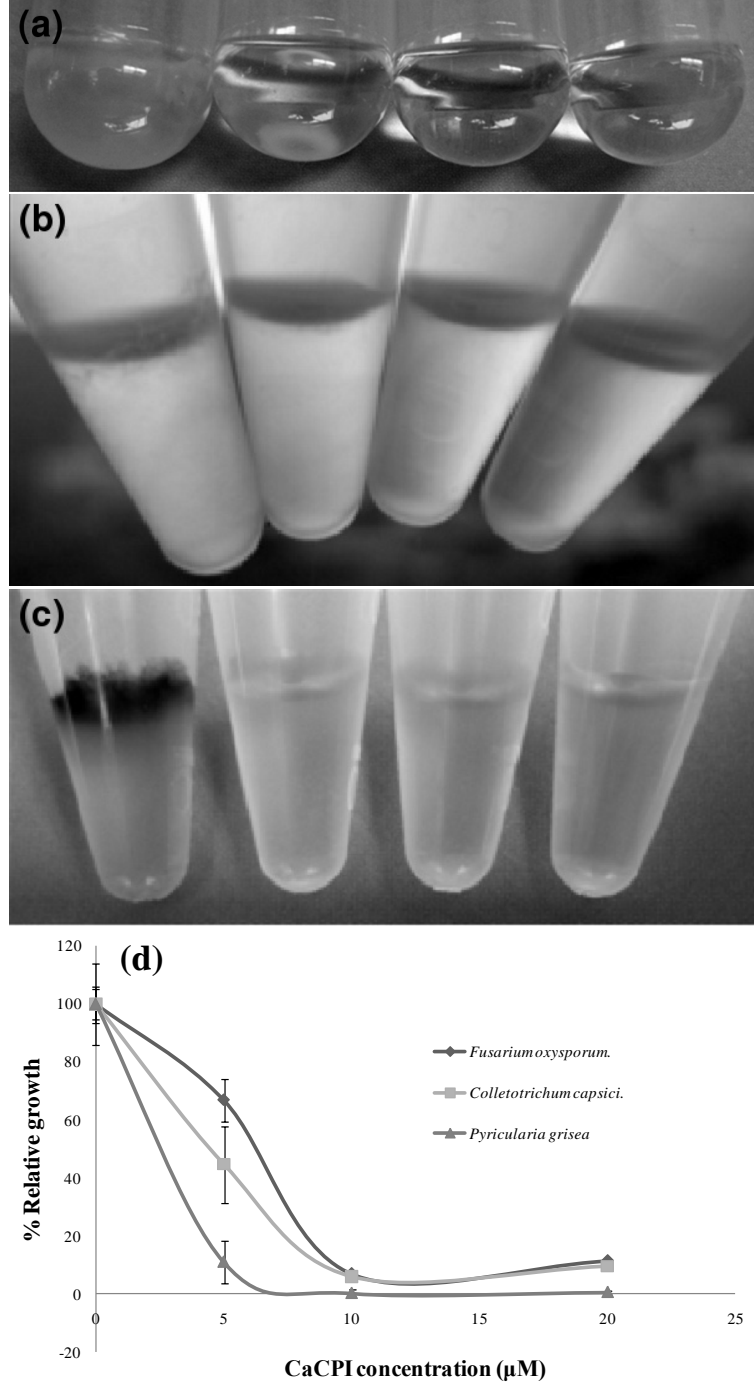

Fig. 5 Growth inhibition assay of three fungal pathogens (a) F. oxysporum, (b) C. capsici, (c) P. grisea by the recombinant CaPI protein. The protein concentrations were varied from $0-20 \mu \mathrm{M}$. (d) relative growth of three fungal species cultured in $1 / 3 \mathrm{PDB}$ with and without various concentrations of $\mathrm{CaCPI}$ proteins. The mycelial growth was monitored by measuring absorbance at $492 \mathrm{~nm}$ after $48 \mathrm{~h}$ of incubation and was presented as a percentage of the fungus growth in the absence of $\mathrm{CaCPI}$.

$P$. cucumerina belong to the necrotrophic group. The hemibiotroph $P$. grisea which lacks the C1A cysteine proteases (cystatin's target enzyme) showed stronger inhibition by cystatins than the necrotrophic $F$. oxysporum or $P$. cucumerina which contain C1A cysteine proteases. It is possible that cystatin was targeted to another type of proteolytic enzymes or that growth inhibition was not mediated by inhibition of cystein proteinases. However, the mechanisms responsible for these differences are still unknown ${ }^{40}$.

When a sensitivity of fungi to CaCPI was compared between $C$. capsici and F. oxysporum. At $5 \mu \mathrm{M}$ of CaCPI concentrations, the growth of $C$. capsici was lesser than that of $F$. oxysporum. While at 10 and $20 \mu \mathrm{M} \mathrm{CaCPI}$, both fungi showed the same level of growth inhibition (Fig. 5). This indicated that C. capsici was more sensitive to the CaCPI protein than $F$. oxysporum at the lower concentrations of the $\mathrm{CaCPI}$ protein.

The maximum concentration of the purified Histagged recombinant Siam tulip cystatin for the inhibition of the growth of the three phytopathogenic fungi (F. oxysporum, C. capsici and P. grisea) was $10 \mu \mathrm{M}$. The cystatin concentrations used to inhibit $F$. oxysporum growth in this study were found to be different from that previously used in other inhibitory assays such as amaranth cystatin AhCPI $(17 \mu \mathrm{M})^{41}$ or strawberry cystatin $(6 \mu \mathrm{M})^{21}$. Although we did not find any reports mentioned an effect of other plant cystatins against $C$. capsici, but there has been a report on chestnut cystatin against $C$. graminicola. The maximum inhibition level was found for a concentration of $9 \mu \mathrm{M}^{18}$. This concentration was very similar to our result. In the case of $P$. grisea, there was no report on the maximum cystatin concentration for growth inhibition but there was some reports on barley cystatins (HvCPI-1 to HvCPI-12). The 50\% growth inhibition $\left(\mathrm{EC}_{50}\right)$ against $P$. grisea was 0.18 $5.08 \mu \mathrm{M}^{40}$. This concentration was also similar to our result (Fig. 5). Our results suggested that Siam tulip cystatin carried antifungal activities at the same level as other plant cystatins.

The inhibitory effects that the recombinant $\mathrm{CaCPI}$ exerted on the growth of these three phytopathogenic fungi were also monitored by microscopic observations (Figs. 6, 7, and 8). In the control (without CaCPI application), we observed the spores or conidia germination in all three fungal species with the development of hyphae (Figs. 6, 7, and 8). The mycelial growths were diminished compared to the control when CaCPI was present in the medium. Greater inhibition of hypha growth was observed at $10 \mu \mathrm{M} \mathrm{CaCPI}$ (Figs. 6, 7, and 8). Interestingly, at $20 \mu \mathrm{M} \mathrm{CaCPI}$ concentration, spore germination of $C$. capsici and conidia germination of $P$. grisea were fully suppressed (Figs. 7d and 8d). These results clearly indicated that the CaCPI contained antifungal activity against these pathogens, F. oxysporum, C. capsici, and P. grisea.

Fusarium and Colletotrichum are serious and common fungal genus which cause significant economic damage to crops worldwide, and have an ex- 

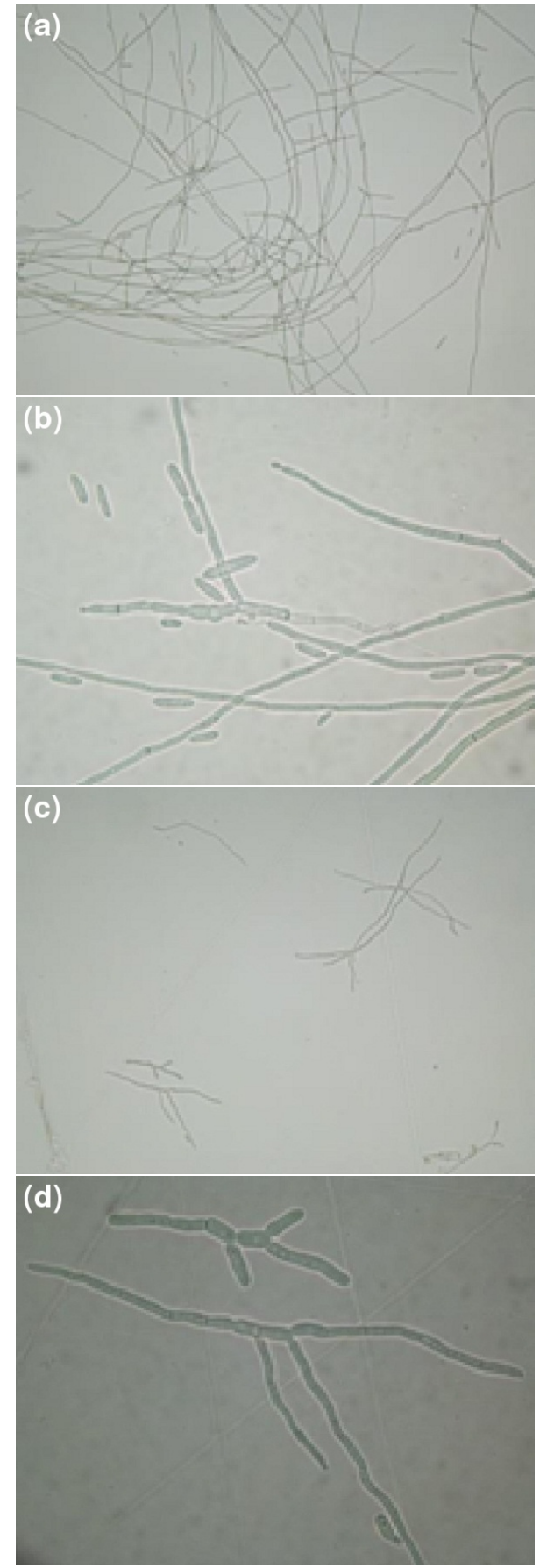

Fig. 6 Microscopic photographs of $F$. oxysporum growth suppression with the recombinant CaCPI under light microscopy at $40 \times(\mathrm{a}, \mathrm{c})$ and $400 \times(\mathrm{b}, \mathrm{d})$ magnifications. F. oxysporum growth without $\mathrm{CaCPI}(\mathrm{a}, \mathrm{c})$, and with $10 \mu \mathrm{M}$ $\mathrm{CaCPI}(\mathrm{b}, \mathrm{d})$.

tremely wide host range including cereals, legumes, ornamentals, vegetables, and fruit trees $25,26,42$.
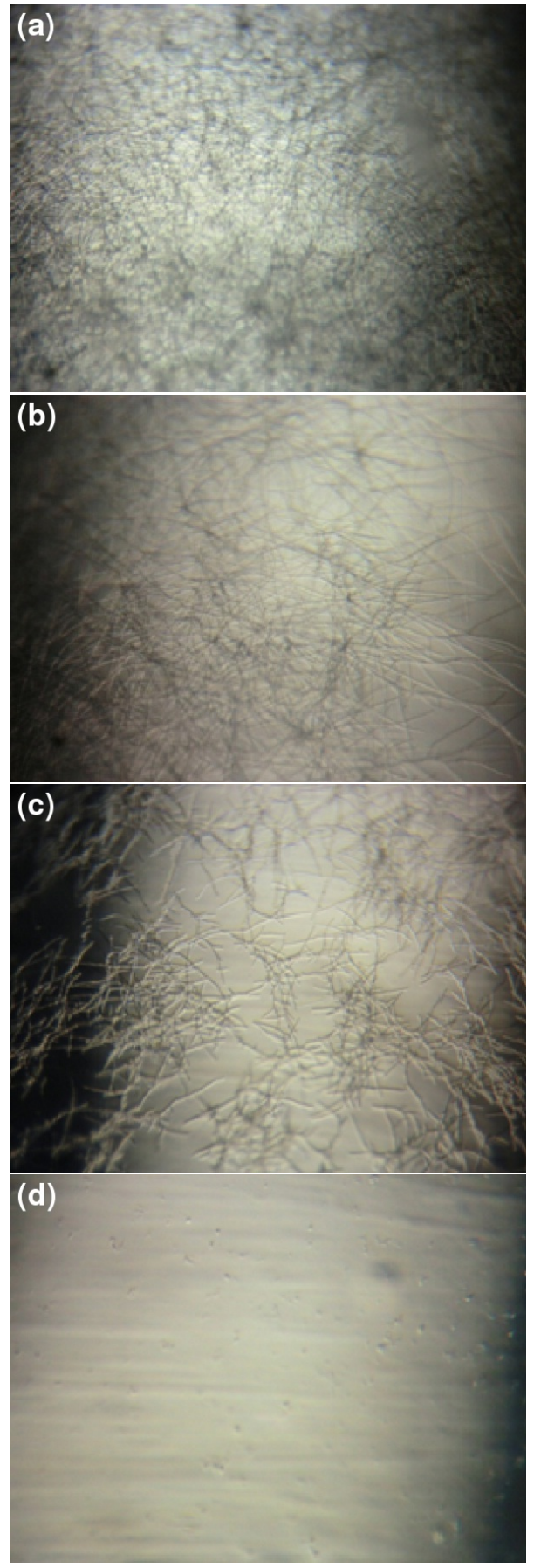

Fig. 7 Microscopic photographs of C. capsici growth suppression with the recombinant CaCPI under light microscopy at $40 \times$ magnification. (a) $C$. capsici growth without CaCPI, (b) with $5 \mu \mathrm{M}$ CaCPI, (c) with $10 \mu \mathrm{M} \mathrm{CaCPI}$, and (d) with $20 \mu \mathrm{M} \mathrm{CaCPI}$.

P. grisea is the causal agent of the rice blast disease, the main fungal disease of rice. Our results show 

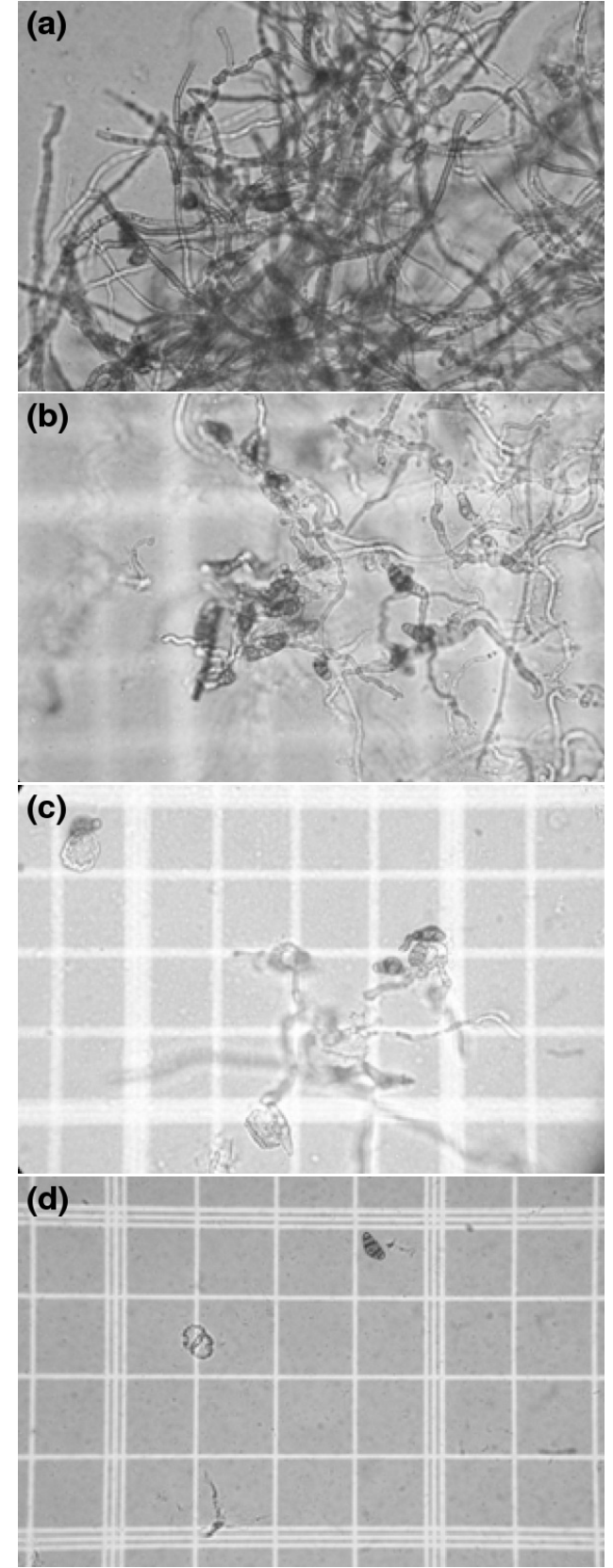

Fig. 8 Microscopic photographs of $P$. grisea growth suppression by the recombinant $\mathrm{CaCPI}$ under light microscopy at $400 \times$ magnifications. (a) $P$. grisea growth without CaCPI, (b) with $5 \mu \mathrm{M} \mathrm{CaCPI}$, (c) with $10 \mu \mathrm{M} \mathrm{CaCPI}$, and (d) with $20 \mu \mathrm{M}$ CaCPI.

that the Siam tulip cystatin could inhibit growth of these pathogenic fungi. Hence this protein may be useful for fungal disease control in these economically important crops in the future.

There are several reports on plant cystatins with antifungal property such as wheat ${ }^{13}$, barley ${ }^{43}$, strawberry $^{21}$, sugarcane ${ }^{19}$, taro $^{22}$, chestnut ${ }^{18}$, hevea rubber $^{44}$, and cacao ${ }^{45}$. But, the mechanisms of antifungal activity demonstrated by cystatins remain unclear. The antifungal properties are most likely related to their inhibition against fungal proteases. However, some reports on barley cystatin (HvCPI) and taro cystatins (CaCPI) demonstrated that the antifungal properties were not associated with activities as proteinase inhibitors ${ }^{20,46}$. Furthermore, the investigation of cystatins from chestnut ${ }^{18}$, Taro ${ }^{22}$ and amaranth ${ }^{41}$ suggested that the antifungal activity of plant cystatins is probably not mediated by fungal proteinase inhibition because the cystatin concentration required to inhibit the mycelial proteolytic activity was very high compared to the concentration that inhibits fungal growth.

\section{CONCLUSIONS}

The cystatin $C a C P I$ gene was cloned and isolated from cDNA library of Siam tulip (Curcuma alismatifolia cv. Chiang Mai Pink), a popular Thai ornamental plant for export. The recombinant CaCPI protein was successfully produced in bacterial expression system. The purified protein exhibited the antifugal activities against growth of phytopathogenic fungi; $F$. oxysporum, C. capsici, and P. grisea. This study of CaCPI protein function could serve as a knowledge base or could be useful for further applications for genetic improvement of economy crop in the future.

Acknowledgements: We gratefully acknowledge the Thailand Research Fund RGJ programme for financial support. We thank Dr Supuk Mahadhanapuk for providing $P$. grisea and Miss Tanavan Jonglang for F. oxysporum and C. capsici.

\section{REFERENCES}

1. Bode W, Engh R, Musil D, Thiele U, Huber R, Karshikov A, Brzin J, Kos J, Turk V (1988) The $2.0 \AA$ crystal structure of chicken egg white cystatin and its possible mode of interaction with cysteine proteinases. EMBO J 7, 2593-9.

2. Machleidt W, Thiele U, Laber B, Assfalg-Machleidt I, Esterl A, Wiegand G, Kos J, Turk V, Bode W (1989) Mechanism of inhibition of papain by chicken egg white cystatin. Inhibition constants of N-terminally truncated forms and cyanogen bromide fragments of the inhibitor. FEBS Lett 243, 234-8.

3. Stubbs MT, Laber B, Bode W, Huber R, Jerala R, Lenarcic B, Turk V (1990) The refined 2.4 $\AA$ X-ray crystal structure of recombinant human stefin $B$ in complex with the cysteine proteinase papain: a novel type of proteinase inhibitor interaction. EMBO J 9, 1939-47. 
4. Rivard D, Girard C, Anguenot R, Vézina L-P, Trépanier S, Michaud D (2007) MsCYS1, a developmentally regulated cystatin from alfalfa. Plant Physiol Biochem 45, 508-14.

5. Fernandes KVS, Campos FAP, Do-Val RR, XavierFilho J (1991) Expression of papain inhibitors during development of cowpea seeds. Plant Sci 74, 179-84.

6. Kumar GNM, Houtz RL, Knowles NR (1999) Ageinduced protein modifications and increased proteolysis in potato seed-tubers. Plant Physiol 119, 89-99.

7. Martínez M, Rubio-Somoza I, Fuentes R, Lara P, Carbonero P, Díaz I (2005) The barley cystatin gene (Icy) is regulated by DOF transcription factors in aleurone cells upon germination. J Exp Bot 56, 547-56.

8. Belenghi B, Acconcia F, Trovato M, Perazzolli M, Bocedi A, Polticelli F, Ascenzi P, Delledonne M (2003) AtCYS1, a cystatin from Arabidopsis thaliana, suppresses hypersensitive cell death. Eur J Biochem 270, 2593-604.

9. Gaddour K, Vicente-Carbojosa J, Lara P, IsabelLamoneda I, Díaz I, Carbonero P (2001) A constitutive cystatin-encoding gene from barley (Icy) responds differentially to abiotic stimuli. Plant Mol Biol 45, 599-608.

10. Van der Vyver C, Schneidereit J, Driscoll S, Turner J, Kunert K, Foyer CH (2003) Oryzacystatin I expression in transformed tobacco produces a conditional growth phenotype and enhances chilling tolerance. Plant Biotechnol J 1, 101-12.

11. Diop NN, Kidric M, Repellin A, Gareil M, d'ArcyLameta A, Pham-Thi AT, Zuily-Fodil Y (2004) A multicystatin is induced by drought-stress in cowpea (Vigna unguiculata (L.) Walp.) leaves. FEBS Lett 577, 545-50.

12. Massonneau A, Condamine P, Wisniewski JP, Zivy M, Rogowsky PM (2005) Maize cystatins respond to developmental cues, cold stress and drought. Biochim Biophys Acta Gene Struct Expr 1729, 186-99.

13. Christova PK, Christov NK, Imai R (2006) A cold inducible multidomain cystatin from winter wheat inhibits growth of the snow mold fungus, Microdochium nivale. Planta 223, 1207-18.

14. Zhao Y, Botella MA, Subramanian L, Niu X, Nielsen SS, Bressan RA, Hasegawa PM (1996) Two woundinducible soybean cysteine proteinase inhibitors have greater insect digestive proteinase inhibitory activities than a constitutive homolog. Plant Physiol 111, 1299-306.

15. Walker AJ, Urwin PE, Atkinson HJ, Brain P, Glen DM, Shewry PR (1999) Transgenic Arabidopsis leaf tissue expressing a modified oryzacystatin shows resistance to the field slug Deroceras reticulatum (Müller). Transgenic Res 8, 95-103.

16. Visal-Shah SD, Vrain TC, Yelle S, Nguyen-Quoc B, Michaud D (2001) An electroblotting, two-step procedure for the detection of proteinases and the study of proteinase/inhibitor complexes in gelatin-containing polyacrylamide gels. Electrophoresis 22, 2646-52.

17. Arai S, Matsumoto I, Emori Y, Abe K (2002) Plant seed cystatins and their target enzymes of endogenous and exogenous origin. J Agr Food Chem 50, 6612-7.

18. Pernas M, López-Solanilla E, Sánchez-Monge R, Salcedo G, Rodríguez-Palenzuela P (1999) Antifungal activity of a plant cystatin. Mol Plant Microbe Interact 12, 624-7.

19. Soares-Costa A, Beltramini LM, Thiemann $\mathrm{OH}$, Henrique-Silva F (2002) A recombinant expression, purification, and antifungal activity. Biochem Biophys Res Comm 296, 1194-9.

20. Marteínez M, López-Solanilla E, RodriguezPalenzuela P, Carbonero P, Díaz I (2003) Inhibition of plant-pathogenic fungi by the barley cystatin Hv-VPI (gene Icy) is not associated with its cysteine-proteinase inhibitory properties. Mol Plant Microbe Interact 16, 876-83.

21. Martínez M, Abraham Z, Gambardella M, Echaide M, Carbonero P, Díaz I (2005) The strawberry gene Cyfl encodes a phytocystatin with antifungal properties. $J$ Exp Bot 56, 1821-9.

22. Yang AH, Yeh KW (2005) Molecular cloning, recombinant gene expression, and antifungal activity of cystatin from taro (Colocasia esculenta cv. Kaosiung No.1). Planta 221, 493-501.

23. Ng TB (2004) Antifungal proteins and peptides of leguminous and nonleguminous origins. Peptides $\mathbf{2 5}$, 1215-22.

24. Levetin E, McMahon K (2003) Plants and Society, $3^{\text {rd }}$ Edn. McGrawHill, Dubuque, Iowa.

25. Beckman CH (1987) The Nature of Wilt Diseases of Plants. APS Press, Am Phytopathol Soc, St Paul, Minnesota.

26. Endah R, Beyene G, Kiggundu A, van den Berg N, Schluter U, Kunert K, Chikwamba R (2008) Elicitor and Fusarium-induced expression of NPR1-like genes in banana. Plant Physiol Biochem 46, 1007-14.

27. Pakdeevaraporn P, Wasee S, Taylor PWJ, Mongkolporn O (2005) Inheritance of resistance to anthracnose caused by Colletotrichum capsici in Capsicum. Plant Breed 124, 206-8.

28. Than PP, Jeewon R, Hyde KD, Pongsupasamit S, Mongkolporn O, Taylor PWJ (2008) Characterization and pathogenicity of Colletotrichum species associated with anthracnose disease on chilli (Capsicum spp.) in Thailand. Plant Pathol 57, 562-72.

29. Nantawanit N, Chanchaichaovivat A, Panijpan B, Ruenwongsa P (2010) Induction o defense response against Colletotrichum capsici in chili fruit by the yeast Pichia guillermondii strain R13. Biol Contr 52, 145-52.

30. Tapia-Tussell R, Quijano-Ramayo A, CortesVelazquez A, Lappe P, Larque-Saavedra A, Perez-Brito D (2008) PCR based detection and characterization of the fungal pathogens Colletotrichum gloeosporioides and Colletotrichum capsici causing anthracnose in 
papaya (Carica papaya L.) in the Yucatan Peninsula. Mol Biotechnol 40, 293-8.

31. Tarnowski TLB, Ploetz RC (2010) First report of Colletotrichum capsici causing postharvest anthracnose on papaya in South Florida. Plant Dis 94, 1065.

32. Talbot N (2003) On the trail of a cereal killer: exploring the biology of Magnaporthe grisea. Annu Rev Microbiol 57, 177-202.

33. Thuan N, Bigirimana J, Roumen E, Van Der Straeten D, Höfte M (2006) Molecular and pathotype analysis of the rice blast fungus in North Vietnam. Eur J Plant Pathol 114, 381-96.

34. Sanger F, Nicklen S, Coulson AR (1977) DNA sequencing with chain terminating inhibitors. Proc Natl Acad Sci USA 74, 5463-7.

35. Pernas M, Sánchez-Monge R, Gómez L, Salcedo G (1998) A chestnut seed cystatin differentially effective against cysteine proteinases from closely related pests. Plant Mol Biol 38, 1235-42.

36. Marchler-Bauer A, Anderson JB, Derbyshire MK, DeWeese-Scott C, Gonzales NR, Gwadz M, Hao L, He S, Hurwitz DI, Jackson JD, Ke Z, Krylov D, Lanczycki CJ, Liebert CA, Liu C, Lu F, Lu S, Marchler GH, Mullokandov M, Song JS, Thanki N, Yamashita RA, Yin JJ, Zhang D, Bryant SH (2007) CDD: a conserved domain database for interactive domain family analysis. Nucleic Acids Res 35, 237-40.

37. Abe M, Arai S (1991) Some properties of a cysteine proteinase inhibitor from corn endosperm. Agr Biol Chem 55, 2417-8.

38. Kondo H, Abe K, Emori Y, Arai S (1991) Gene organization of oryzacystatin-II, a new cystatin superfamily member of plant origin, is closely related to that of oryzacystatin-I but different from those of animal cystatins. FEBS Lett 278, 87-90.

39. Margis R, Reis EM, Villeret V (1998) Structural and phylogenetic relationships among plant and animal cystatins. Arch Biochem Biophys 359, 24-30.

40. Carrillo L, Herrero I, Cambra I, Sánchez-Monge R, Diaz I, Martinez M (2011) Differential in vitro and in vivo effect of barley cysteine and serine protease inhibitors on phytopathogenic microorganisms. Plant Physiol Biochem 49, 1191-200.

41. Valdes-Rodriguez S, Cedro-Tanda A, AguilarHernandez V, Cortes-Onofre E, Blanco-Labra A, Guerrero-Rangel A (2010) Recombinant amaranth cystatin (AhCPI) inhibits the growth of phytopathogenic fungi. Plant Physiol Biochem 48, 469-75.

42. Freeman S (2000) Genetic diversity and host specificity of Colletotrichum species on various fruits. In: Prousky D, Freeman S, Dickman MB (eds) Colletotrichum. Host Specificity, Pathology and Host-Pathogen Interaction, APS Press, St Paul, Minnesota, pp 131-44.

43. Abraham Z, Martinez M, Carbonero P, Diaz I (2006) Structural and functional diversity within the cystatin gene family of Hordeum vulgare. J Exp Bot 57,
4245-55.

44. Bangrak P, Chotigeat W (2011) Molecular cloning and biochemical characterization of a novel cystatin from Hevea rubber latex. Plant Physiol Biochem 49, 244-50.

45. Pirovani CP, da Silva Santiago A, dos Santos LS, Micheli F, Margis R, da Silva Gesteira A, Alvim FC, Pereira GA, de Mattos Cascardo JC (2010) Theobroma cacao cystatins impair Moniliophthora perniciosa mycelial growth and are involved in postponing cell death symptoms. Planta 232, 1485-97.

46. Wang KM, Kumar S, Cheng YS, Venkatagiri S, Yang $\mathrm{AH}$, Yeh KW (2008) Characterization of inhibitory mechanism and antifungal activity between group-1 and group-2 PhyCys from taro (Colocasia esculenta). FEBS J 275, 4980-9. 